\title{
Extension of the Periods for Consent to and Payment of Quota Increases
}




\title{
INTERNATIONAL MONETARY FUND
}

December 2016

\section{IMF POLICY PAPER}

\section{EXTENSION OF THE PERIODS FOR CONSENT TO AND PAYMENT OF QUOTA INCREASES}

IMF staff regularly produces papers proposing new IMF policies, exploring options for reform, or reviewing existing IMF policies and operations. The following documents have been released and are included in this package:

- The Staff Report on Extension of the Periods for Consent to and Payment of Quota Increases, prepared by IMF staff. The proposed decision in the paper was approved by the Executive Board on December 27, 2016.

The IMF's transparency policy allows for the deletion of market-sensitive information and premature disclosure of the authorities' policy intentions in published staff reports and other documents.

\author{
Electronic copies of IMF Policy Papers \\ are available to the public from \\ http://www.imf.org/external/pp/ppindex.aspx

\section{International Monetary Fund Washington, D.C.}




\title{
INTERNATIONAL MONETARY FUND
}

December 21, 2016

\section{EXTENSION OF THE PERIODS FOR CONSENT TO AND PAYMENT OF QUOTA INCREASES}

\author{
Approved By \\ Andrew Tweedie \\ Prepared by the Finance Department \\ (In consultation with the Legal and Secretary's Departments)
}

1. This paper proposes a further six-month extension of the period for members to consent to an increase in their quotas under the Fourteenth General Review of Quotas ("Fourteenth Review") through June 30, 2017. ${ }^{1}$ The current deadline is due to expire on December 30, 2016. ${ }^{2}$ However, Board of Governors Resolution No. 66-2 provides that the Executive Board may extend the period for consent as it may determine. An extension under Resolution No. 66-2 will also extend the periods of consent for quota increases under the 2008 Reform of Quota and Voice (Resolution No. 63-2) and the Eleventh General Review of Quotas (Resolution No. 53-2). ${ }^{3}$

2. This paper also proposes a further six-month extension of the period for payment of quota increases under the Fourteenth Review, and an extension for the payment of the quota increases under the 2008 Reform, through June 30, 2017.

3. As of December 15, 2016, eight members had not yet consented to their proposed quota increases under Resolution No. 66-2 (see Appendix I). ${ }^{4}$ Two of those members (Somalia and Sudan) are currently not eligible to consent to their quota increases under the $11^{\text {th }}$ and $14^{\text {th }}$ General Reviews due to protracted arrears to the Fund in General Resources Account. ${ }^{5,6}$

\footnotetext{
${ }^{1}$ See Board of Governors Resolution No. 66-2, Fourteenth General Review of Quotas and Reform of the Executive Board, which can be found at: http://www.imf.org/external/pubs/ft/sd/index.asp?decision=66-2.

2 See Extension of the Periods for Consent to and Payment of Quota Increases (6/27/2016).

${ }^{3}$ Paragraph 7 of Resolution No. 66-2 states: "For members that have not yet consented to their increases in quotas under the Eleventh General Review and under Board of Governors Resolution No. 63-2, the deadline for consent to such quota increases shall be the date determined by or under paragraph 4 above".

${ }^{4}$ Palau has not consented to its quota increase under the 2008 Reform. It has, however, consented to its quota increase under the Fourteenth Review but has not made payment of its quota increase.

${ }^{5}$ Resolutions No. 53-2 and 66-2 provide that no member with overdue repurchases, charges, or assessments to the General Resources Account may consent to, or pay for, its quota increase until it becomes current with respect to these obligations.

${ }^{6}$ See Review of the Fund's Strategy on Overdue Financial Obligations (8/20/2012), www.imf.org/external/np/pp/eng/2012/082012.pdf.
} 
4. For the Fourteenth Review, under Board of Governors Resolution No. 66-2, each member shall pay to the Fund the increase in its quota within 30 days after the later of (a) the date on which it notifies the Fund of its consent, or (b) the date on which all of the general effectiveness conditions for the quota increases under the Fourteenth Review are met, provided that the Executive Board may extend the payment period as it may determine. ${ }^{7}$ The initial 30 -day period for payments has been extended five times, most recently through December 30, $2016 .{ }^{8}$ Continued progress is being made in implementing the quota payments. ${ }^{9}$ However, some members have indicated that they require additional time to complete internal procedures for the payment of quota increases. Staff is following up with the authorities in each of these cases to facilitate timely arrangements for payments.

5. With respect to the 2008 Reform, among members that have consented to their ad hoc quota increases under the 2008 Reform, two members - Eritrea and the Syrian Arab Republic require additional time to complete the payments for their ad hoc quota increases. The Executive Board has previously extended the payment deadline for these countries, most recently in June 2016. ${ }^{10}$ Their deadline for payment is currently December 30, 2016.

6. Synchronizing the extension of the periods for consent to and payment of quota increases has allowed streamlining of administrative procedures and adoption of associated decisions. While it is important to emphasize that all members who have not yet consented to their Fourteenth Review quota increases should do so without further delay, and that members who have consented to their quota increases should make their quota payments in a timely manner, a new uniform six-month extension in the periods for consent to and payment of quota increases would seem appropriate.

7. In these circumstances, it is proposed to extend the period for consent under Resolution No. 66-2 to end at 6:00 p.m., Washington time, on June 30, 2017. It is also proposed that the Executive Board extend the period for payment of the quota increases under the Fourteenth General Review of Quotas through June 30, 2017 for those members whose quota payments would otherwise be due earlier. It is also proposed that the Executive Board extend the period for payment of the quota increases under the 2008 Reform for Eritrea and the Syrian Arab Republic through June 30, 2017.

\footnotetext{
7 See paragraph 5 in Board of Governors Resolution No. 66-2, Fourteenth General Review of Quotas and Reform of the Executive Board.

8 See Extension of the Periods for Consent to and Payment of Quota Increases (6/27/2016).

${ }^{9}$ As of December 15, of the 181 members that had consented to their quota increases under the Fourteenth Review, 175 members had paid their quota increases.

${ }^{10}$ See Extension of the Periods for Consent to and Payment of Quota Increases (6/27/2016).
} 


\section{Proposed Decisions}

Accordingly, the following decisions, each of which may be adopted by a majority of the votes cast, are proposed for adoption by the Executive Board:

\section{Decision 1: Extension of the Period for Consent to Increase Quotas Under the Fourteenth General Review of Quotas}

Pursuant to paragraph 4 of Resolution No. 66-2, Fourteenth General Review of Quotas and Reform of the Executive Board, the Executive Board decides that notices of consent from members to increases in their quotas must be received in the Fund by 6:00 p.m., Washington time, on June 30, 2017.

\section{Decision 2: Extension of the Period of Payment of Quota Increase Under the Fourteenth General Review of Quotas}

Pursuant to paragraph 5 of Board of Governors Resolution No. 66-2, Fourteenth General Review

of Quotas and Reform of the Executive Board, the Executive Board decides that each member shall pay to the Fund the increase in its quota under the Fourteenth General Review by the later of (a) June 30, 2017, or (b) 30 days after the date on which it notifies the Fund of its consent.

\section{Decision 3: Extension of the Period of Payment of Quota Increase Under the 2008 Reform}

Pursuant to Paragraph 4 of the Resolution of the Board of Governors No. 63-2, Reform of Quota and Voice in the International Monetary Fund, the Executive Board decides to extend the period for payment of quota increase by Eritrea and the Syrian Arab Republic through June 30, 2017. 


\section{Appendix I. Status of Members' Consents to Increases in Quotas Under the Fourteenth General Review of Quotas}

(as of December 15, 2016)

The eight members listed below have not yet consented to their respective quota increases under the Board of Governors Resolution No. 66-2:

$\begin{array}{ll}\text { Bolivia } & \text { Micronesia, Federated States of } \\ \text { Cabo Verde } & \text { Somalia } \\ \text { Eritrea } & \text { Sudan } \\ \text { Kyrgyz Republic } & \text { Syrian Arab Republic }\end{array}$

